\title{
Analysis of Geological and Geophysical Datasets for Radioelement Exploration in Kab Amiri Area, Central Eastern Desert, Egypt
}

\author{
Ibrahim Gaafar ${ }^{1}$ and Hatem Aboelkhair ${ }^{*}, 2$ \\ ${ }^{I}$ Nuclear Materials Authority (NMA), Studies Department, P.O. Box 530 Maadi, Cairo, Egypt \\ ${ }^{2}$ Damietta University, Faculty of Science, Geology Department, P.O. Box 3417 New Damietta, Egypt
}

\begin{abstract}
Detailed geological mapping description of the different granitic types of Kab Amiri pluton were integrated with geophysical (ground gamma ray spectrometry and aeromagnetic) data to identify and map the distribution of radioelement concentrations as well as delineate structural trends that control the mineralized zones in the study area. The geologic studies revealed the existence of four granite varieties namely; biotite granite, garnet two mica granite, muscovite granite, and episyenite. The structural interpretation of geological and geophysical data revealed two intersecting sets of NW and NE-trending faults. The NW-trending set of faults is younger than the NE-trending set where the latter is dissected and displaced by the former. Interpretations of radiometric data revealed the presence of radioactive anomalies southwards that indicate an original increase in uranium contents in the same direction. It could be related to the prevailing NE and ENE fault trends. The southern anomalous zone is related to a very high episyenitization and uranium mobilization. It exhibits a sharp increase in the eU concentrations reaching $370 \mathrm{ppm}$ resulting in a high eU/eTh ratio, approaching 4.5 and, characterized by oval shape trending in the NE direction. Some areas along the peripheral part of Kab Amiri pluton are episyenitized and show a remobilization of uranium. These areas are mostly controlled by faults mainly trending ENE. In the case of the episyenite zone, strong mobilization of uranium is expected to host epigenetic uranium occurrences because more uranium is available. It is obvious that the episyenite rocks of high permeability have higher levels of uranium and their ratios. Thus, these rocks act as an important reservoir for Umineralization bearing solutions.
\end{abstract}

Keywords: Gamma ray spectrometry, aeromagnetic, radioelement mapping, uranium.

\section{INTRODUCTION}

Basement rocks cover about one tenth of the land surface of Egypt. They form mountainous terrain in southern Sinai, the Eastern Desert (ED) and the Gebel Uweinat area, as well as small inliers with low relief in the southern part of the Western Desert. The basement rocks of Sinai, the Eastern and Western Deserts, Sudan, Ethiopia and Somalia constitute the Nubian Shield that had formed as a contiguous part of the Arabian Shield of the Arabian Peninsula, prior to the opening of the Red Sea, less than 30 Ma ago [1].

The Eastern Desert is arbitrarily divided into a northern (NED), central (CED), and southern portion (SED) by two rough lines running from Qena to Safaga and from Idfu to Marsa Alam. These subdivisions confine parts with common geographic and lithostructural discontinuities [1,2]. The Kab Amiri pluton is located in the central ED (Fig. 1) between latitudes $26^{\circ} 17^{\prime}-26^{\circ} 23^{\prime} \mathrm{N}$ and longitudes $33^{\circ} 31^{\prime}-33^{\circ} 36^{\prime} \mathrm{E}$. It can be accessed from $85 \mathrm{~km}$ post Qena-Safaga asphaltic road.

The Kab-Amiri granite pluton is one of the most important anomalous radioactive zones in the Central Eastern Desert (CED) [3]. It was discovered by Ammar (1993) [4]. Even though, he did not find any visible uranium mineralization with the exception of some grains of

*Address correspondence to this author at the Damietta University, Faculty of Science, Geology Department, P.O. Box 3417 New Damietta, Egypt; Tel: +20 114 4897466; Fax: +20 57 2403868; E-mail: h.aboelkhair@du.edu.eg

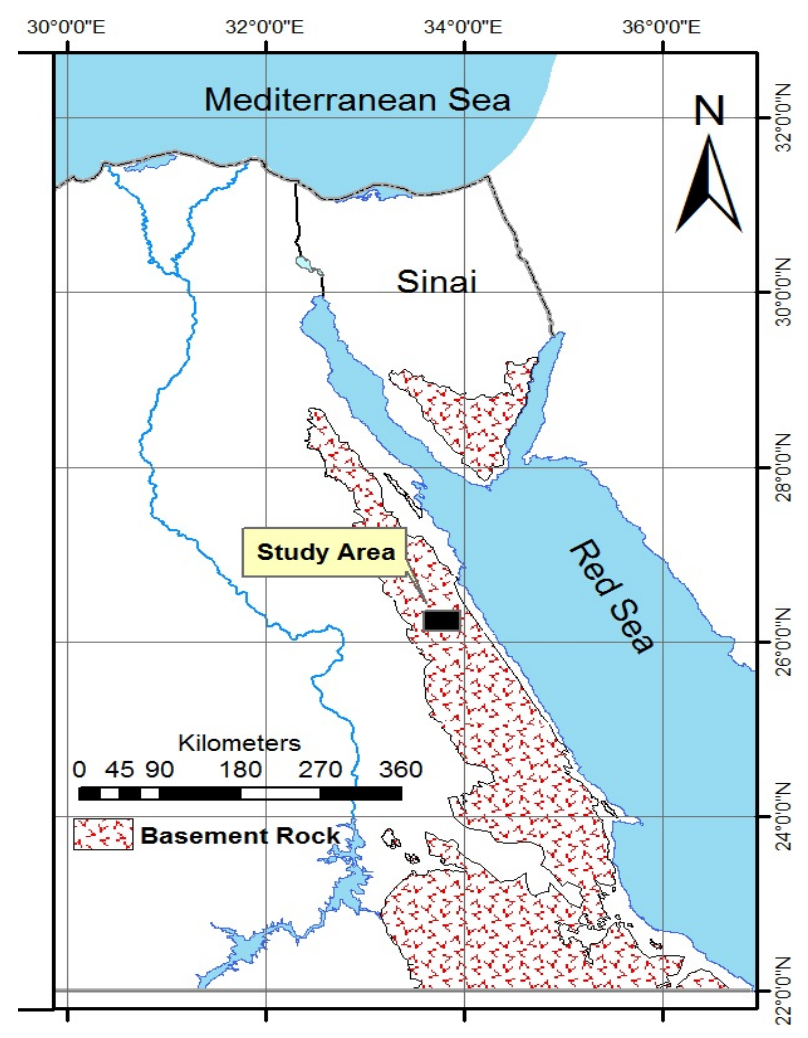

Fig. (1). Location map of Kab Amiri area, Central Eastern Desert, Egypt. 
walfenite at the surface, he reported higher $\mathrm{U} / \mathrm{Th}$ ratios than normal. Recent geological reconnaissance and spectrometric studies indicate a U-remobilization process associated with large alteration features that resulted in episyenitization of the granite, which enlarged the U-ore potential in the area compared to other sites under development. Regarding the importance of the Kab Amiri episyenitized granite pluton as an example of uranium mineralizations the need arises for detailed geological and geophysical studies in order to locate trends of uranium remobilization and concentrations.

The use of gamma ray spectrometry as a tool for mapping radioelement concentrations has found widespread acceptance in diverse fields [5]. The method has evolved over several decades and continues to develop [6]. Gamma ray spectrometry has been used for many years by those exploring for uranium. However, with the development of spectrometers in the 1960s, the scope of the gamma ray method was expanded to include geological and environmental mapping [7]. Gamma-ray spectrometry can also be used to search for minerals other resources, such as heavy minerals, beach sands and phosphates $[8,9]$.

The aeromagnetic survey technique is a powerful tool in delineating the regional geology (lithology and structure) of buried basement terrains. Aeromagnetic surveys map the variation of the geomagnetic field, which occurs due to changes in type and percentage of magnetite minerals in the rock. It reflects variations in the distribution and type of magnetic minerals below the surface. Magnetic minerals can

(a)

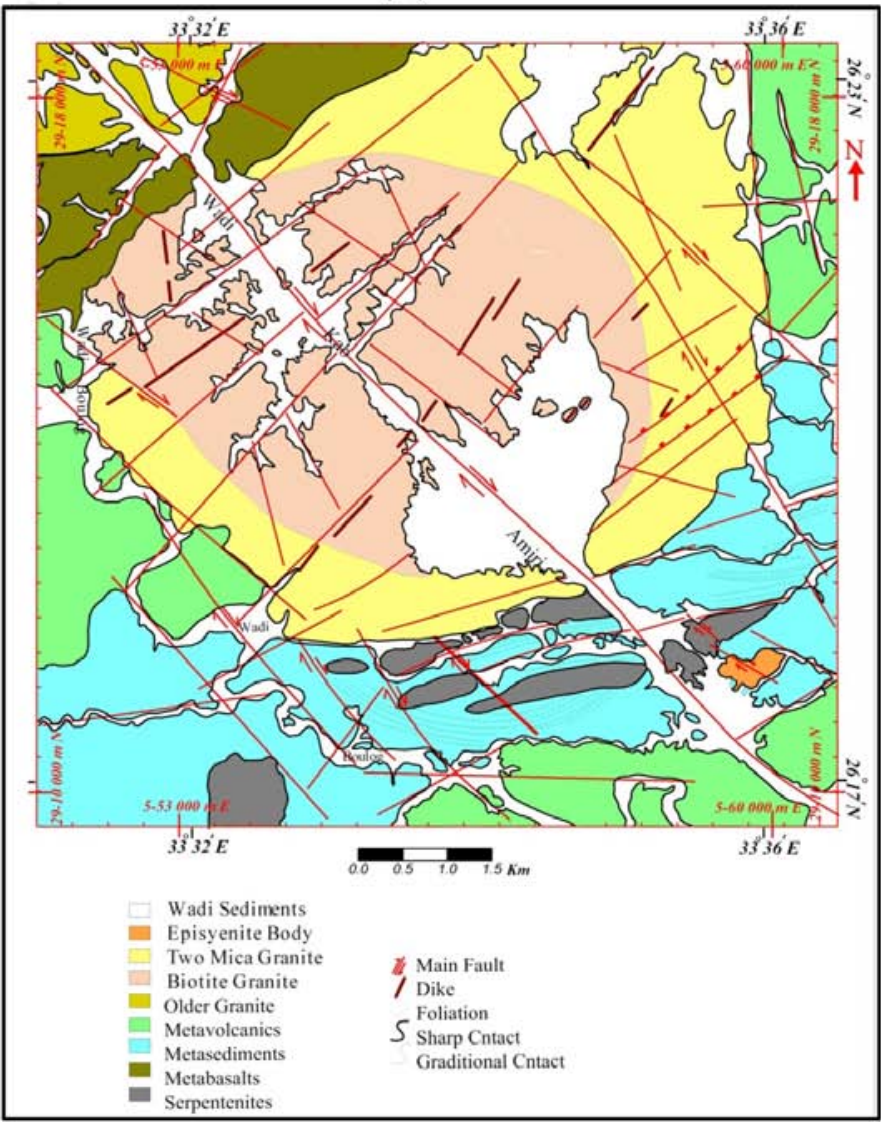

be mapped from the surface to greater depths in the crust depending on the dimension, shape and magnetic property of the deposit. Sedimentary formations are usually nonmagnetic and consequently have little effect whereas mafic and ultramafic igneous rocks exhibit greater variation. These contrasts in magnetic signatures enhance the usefulness of the technique to map bedrock geology concealed below sedimentary cover [10].

The main objective of this study is the detection and mapping of radioactive anomalies in The Kab Amiri area, Central Eastern Desert, Egypt using integrated geological and geophysical datasets. This objective is also extended to include the delineation of structural trends that may control the distribution of the radioelements in the study area and to further evaluate the mineral potential of this area.

\section{GEOLOGIC SETTING OF THE STUDY AREA}

The Kab Amiri granite pluton forms a conspicuous circular topographic feature measuring $6 \times 8 \mathrm{~km}$ in size and crosscut by a major NW-SE wadi. This pluton is composed of two concentric parts. The inner part consists of biotite granite exhibiting low relief (Fig. 2a). The outer part comprises of garnetiferous two-mica granite of relatively high relief ranging in width from 0.5 to $1.5 \mathrm{~km}$. The Kab Amiri pluton intrudes mafic-ultramific rocks thrusted over sheared arc-related volcanic and volcano-sedimentary rock associations (Fig. 2b).

Fig. (2). (a) Geologic map for Kab Amiri area, Central Eastern Desert, Egypt. (b) Structural Lineaments map with geologic background for Kab Amiri area, Central ED, Egypt. 
Approximately $1.5 \mathrm{~km}$ south from the southern contact of the Kab Amiri granite pluton, a small body $(200 \mathrm{~m} \times 400 \mathrm{~m})$ of muscovitized granite is exposed with moderate relief. The rock is medium grained, pink in colour and intrudes into older metasediments. It shows hydrothermal alteration causing dissolution of magmatic quartz. The removal of quartz leaves vugs, whose volumes and shapes are identical to the original quartz boundaries when no later tectonic disturbance occurs. This dissolution of quartz results in the mineralogical compositions somewhat similar to that of a syenite; this explains the word episyenite commonly used in the French literature. The contact between granite and quartz-depleted granite is often abrupt or restricted to narrow zone a few centimeters broad.

The process of alteration results in the increased permeability of the altered granites and consequently when such altered rocks undergo mineralization (e.g., by U-, Sn-, $\mathrm{W}-$, and Au- bearing solutions) they act as important reservoir rocks for fluids or ores. Previous studies of quartzdepleted granites $[11,12]$ noted that, in most cases, the magmatic textures remain unchanged apart from the disappearance of quartz.

\section{PETROGRAPHIC DESCRIPTION}

The petrographic analysis revealed the existence of three granite varieties namely; 1) biotite granite, 2) two-mica granite, and 3) episyenite. The biotite granites are equigranular (sometimes porphyritic) with greyish-pink colour. The rocks are composed of quartz (35\%), plagioclase $(29 \%)$, perthite $(28 \%)$ and biotite $(5 \%)$. Chlorite and muscovite are secondary minerals (3\%). Fluorite, allanite and opaques are the main accessory minerals. The two-mica granites are composed of perthite $(37 \%)$, quartz (30\%) and plagioclase (23\%), with biotite (3\%) and muscovite (3\%) Garnet, fluorite and allanite are accessory minerals. The episyenites are composed of K-feldspar (orthoclase and orthoclase microperthite; 50\%), plagioclase $(40 \%)$, and muscovite $(10 \%)$, as essential minerals. Calcite is a secondary mineral. This rock exhibits lower quartz contents (possibly due toincipient episyenitization as verified in thin section [13]).

Reconnaissance radioactivity studies of the different granitic varieties of the Kab-Amiri pluton indicate variability in radioelement concentrations $(\mathrm{K}, \mathrm{eU}, \mathrm{eTh})$. These variations reflect both primary rock fractionation and secondary alteration features.

\section{STRUCTURAL INTERPRETATION OF FIELD GEOLOGY}

Linear structures were measured on aerial photographs at a scale of 1:40,000. Faults measured in the field and the liner structures display nearly similar directions (Fig. 2b). Most faults dip at steep angles. The faults in the area have two main trends, NW and NE with a smaller number of faults trending in a NNW direction. The NW trending faults are the most predominant and most recent faults in the area and commonly display a right lateral strike-slip movement (Fig. 2b). This fault set is nearly parallel to the Gulf of Suez trend and is considered by many authors to be relatively older than the NNE Gulf of Aqaba trend [14]. The NE trending faults mostly dip at high angles to the west, towards their down thrown blocks with a normal dip-slip movement. The relatively minor NNW fault set is nearly parallel to Gulf of Suez and Red Sea trend. These NNW trending are mainly right lateral strike-slip faults [13].

Basic dykes in the area can be classified as post-granite dykes. The frequency distribution of these dykes according to their direction trends is plotted on a rose diagram (Fig. 2b). The dominant trend is NE followed by NNE. A minor number of dykes have an N-S direction. Basic dykes that intrude the younger granite in $\mathrm{NE}$ direction indicate that faults parallel to these dyke trends are mostly normal faults and the NW trends are older than NE trends.

Folding is represented by a major anticline fold associated with the ophiolitic rocks in the southern sector of the study area. Detailed examination and correlation between the field structural measurements and the basement tectonic map indicate that this major anticline fold has a fold axis plunging about $21^{\circ}$ in a $\mathrm{N} 65^{\circ} \mathrm{E}$ direction and axial plane that strikes $\mathrm{N} 60^{\circ} \mathrm{E}$ with a dip of $76^{\circ} \mathrm{E}$ in the eastern part of the area. In the western part of this anticline, the fold axis changes orientation and plunges $16^{\circ}$ in a $\mathrm{S} 74^{\circ} \mathrm{E}$ direction and has an axial plane striking $\mathrm{N} 82^{\circ} \mathrm{W}$ with a dip $68^{\circ} \mathrm{W}$. The direction of the strike of this anticline fold is the main direction of the foliations in these folded rocks.

\section{ANALYSIS AND PROCESSING OF AEROMAGNETIC DATA}

The study area is included in the airborne magnetic survey that covers the Eastern Desert of Egypt conducted between 1982 and 1984 by Aero-Service Division, Western Geophysical Company of America. These surveys were conducted along parallel flight lines at $1.5 \mathrm{~km}$ spacing. Tie lines were oriented perpendicular to flight lines and spaced at $10 \mathrm{~km}$ intervals. The altitude of the airplane during survey

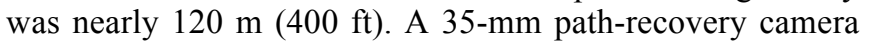
was used to record the ground track of the aircraft [15]. The purpose of the survey was to provide data, which would be of assistance in identifying and assessing the mineral, petroleum and ground water sources of the region and subsequently stimulate interest for further exploration.

The regional-residual separation of magnetic anomaly was applied to the RTP magnetic map of the study area. Two main average magnetic interfaces at depths of 0.5 and $1.2 \mathrm{~km}$ below the measuring level were calculated through the application of a power spectrum technique. Filtering assisted in the discrimination between shallow and deep sources of magnetic anomalies and produced the regional and residual magnetic component maps and hence the two basement tectonic maps were constructed at the two interfaces.

\section{Interpretation of Aeromagnetic Data}

The interpretation of magnetic data in the study area is mainly carried out on the RTP magnetic map (Fig. 3), the regional-component from deep-seated sources (Fig. 4) and the residual-component from near surface sources (Fig. 5).

A good correlation was found between magnetic features and the geologic map. The basic lithologic units possess high magnetic response, while the more acidic units have a 


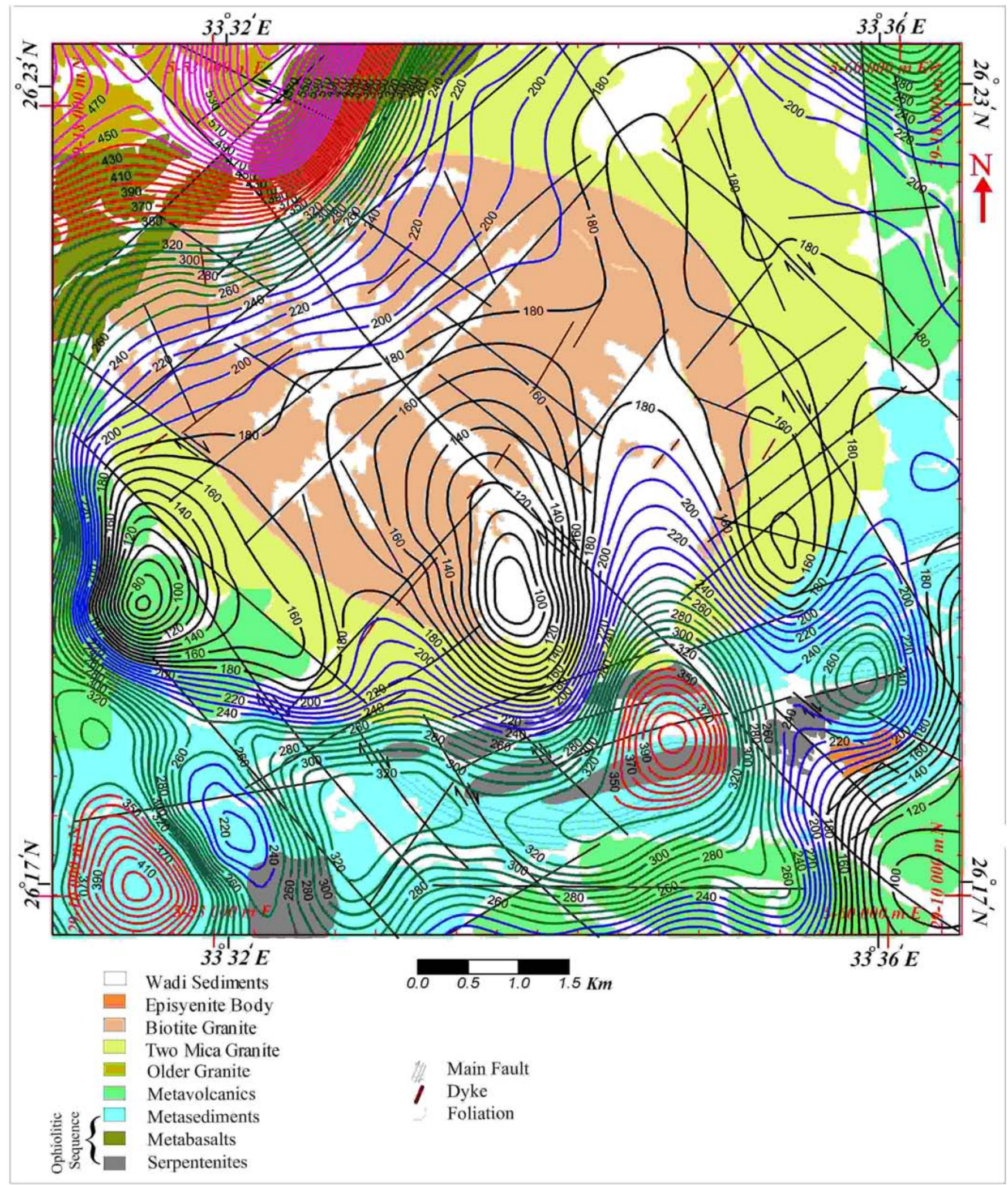

Fig. (3). Total Intensity Aeromagnetic map reduced to the north magnetic pole (RTP) with geologic background for Kab Amiri area, Central ED, Egypt.

generally low magnetic response. The contact between the granitic pluton with the metavolcanics and metasediments on the eastern central part of the geologic map is not clearly defined on the magnetic maps. One of the explanations of this discrepancy would be that the magnetic effects of the local or near-surface geological features and the deep geological structures are not conforming, or that these metavolcanics are more acidic in composition. 


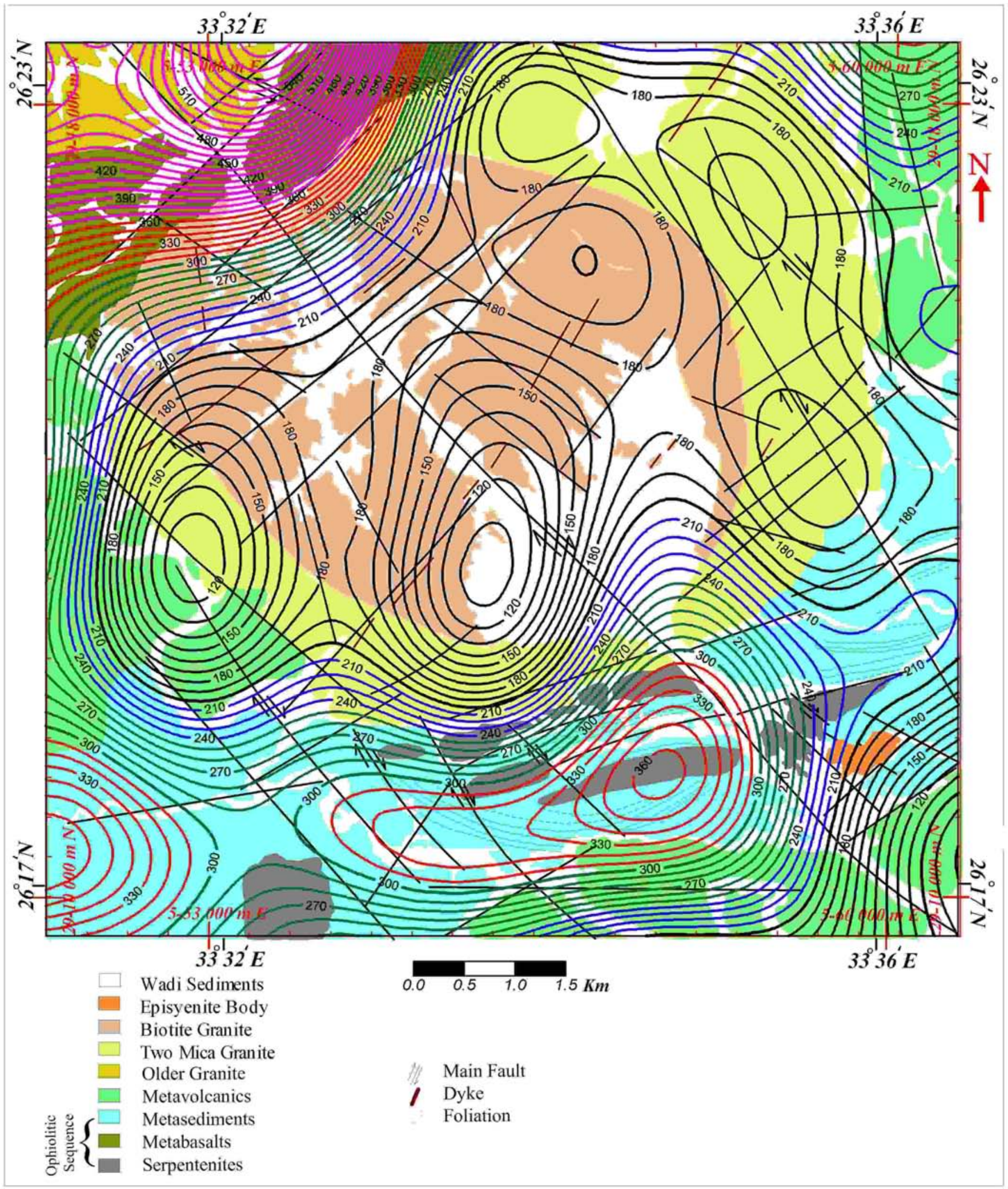

Fig. (4). Regional Aeromagnetic-Component contour map at Interface $1.2 \mathrm{~km}$, with geologic background for Kab Amiri area, Central ED, Egypt.

\section{Structural Interpretation of Aeromagnetic Data}

In the present study, the structural interpretation of the aeromagnetic survey data was carried out through the construction of a tectonic map (Fig. 6). It is based mainly on the original total magnetic intensity R.T.P. as well as the regional (deep-seated) and residual (near-surface) magneticcomponent maps. The regional and residual structures (Figs. 


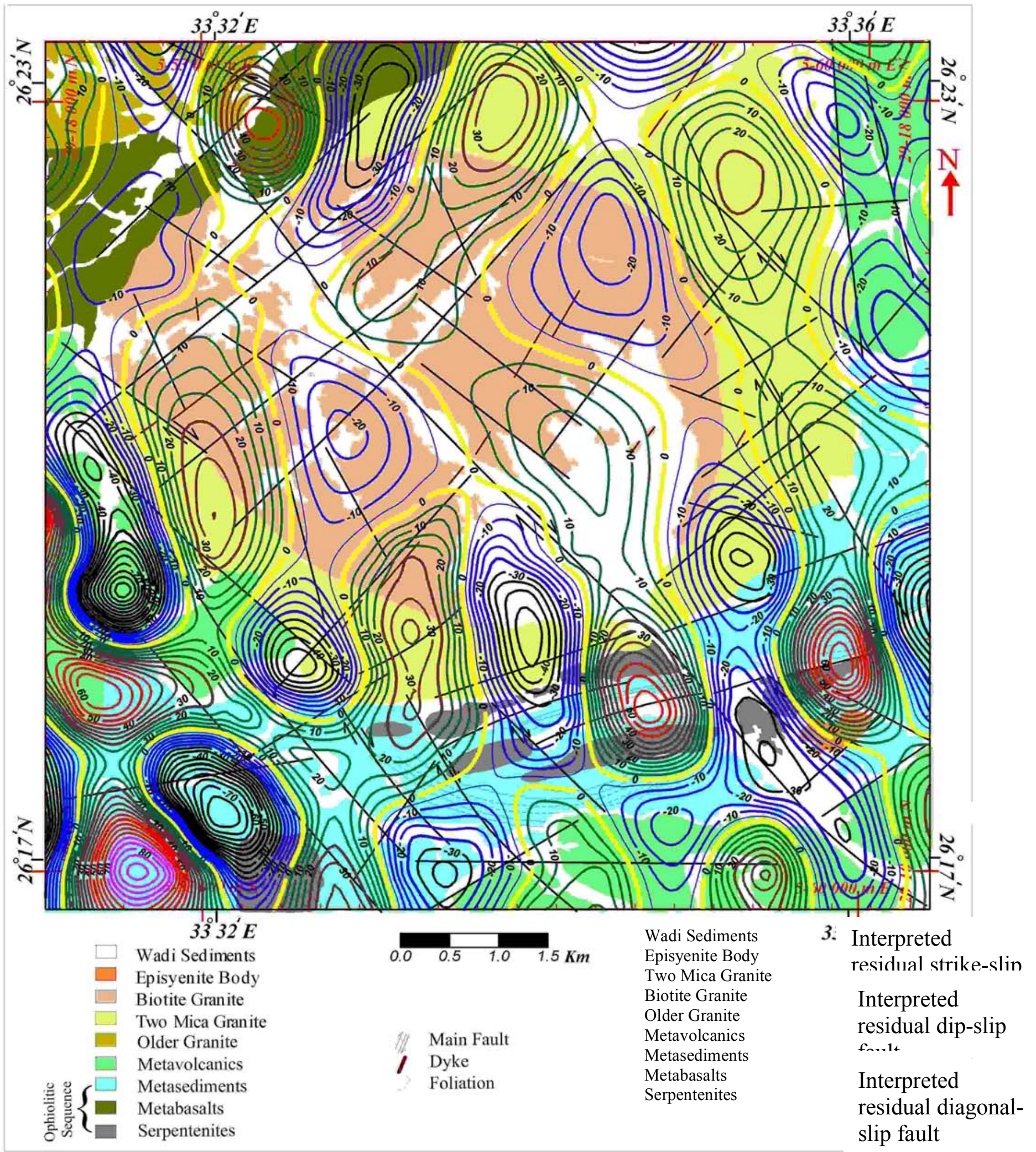

Fig. (5). Residual Aeromagnetic - Component contour map, at Interface $0.5 \mathrm{~km}$ with geologic background for Kab Amiri area, Central ED, Egypt.

$7,8)$ are deduced from the regional and residual magneticcomponent maps. In mapping such structures, the following factors were taken into consideration:
The southern part of the study area is characterized by a broad belt of high magnetic anomalies oriented at WNW to ENE directions and over a large areal extent and with a long wavelength particularly in the central part of this zone. The 
magnetic gradients decrease gradually towards the south away from the Kab Amiri granitic pluton. This reflects the dipping of the causative bodies toward the south-southeast. Moreover, the granitic bodies are deeply rooted and extend outside the mapped region at depth. Field relationships reflect thrusting of serpentinites over metasediments. These relationships suggest that these bodies represent a major limb of an anticline and that the Kab Amiri granitic pluton was intruded along its axial plane. 


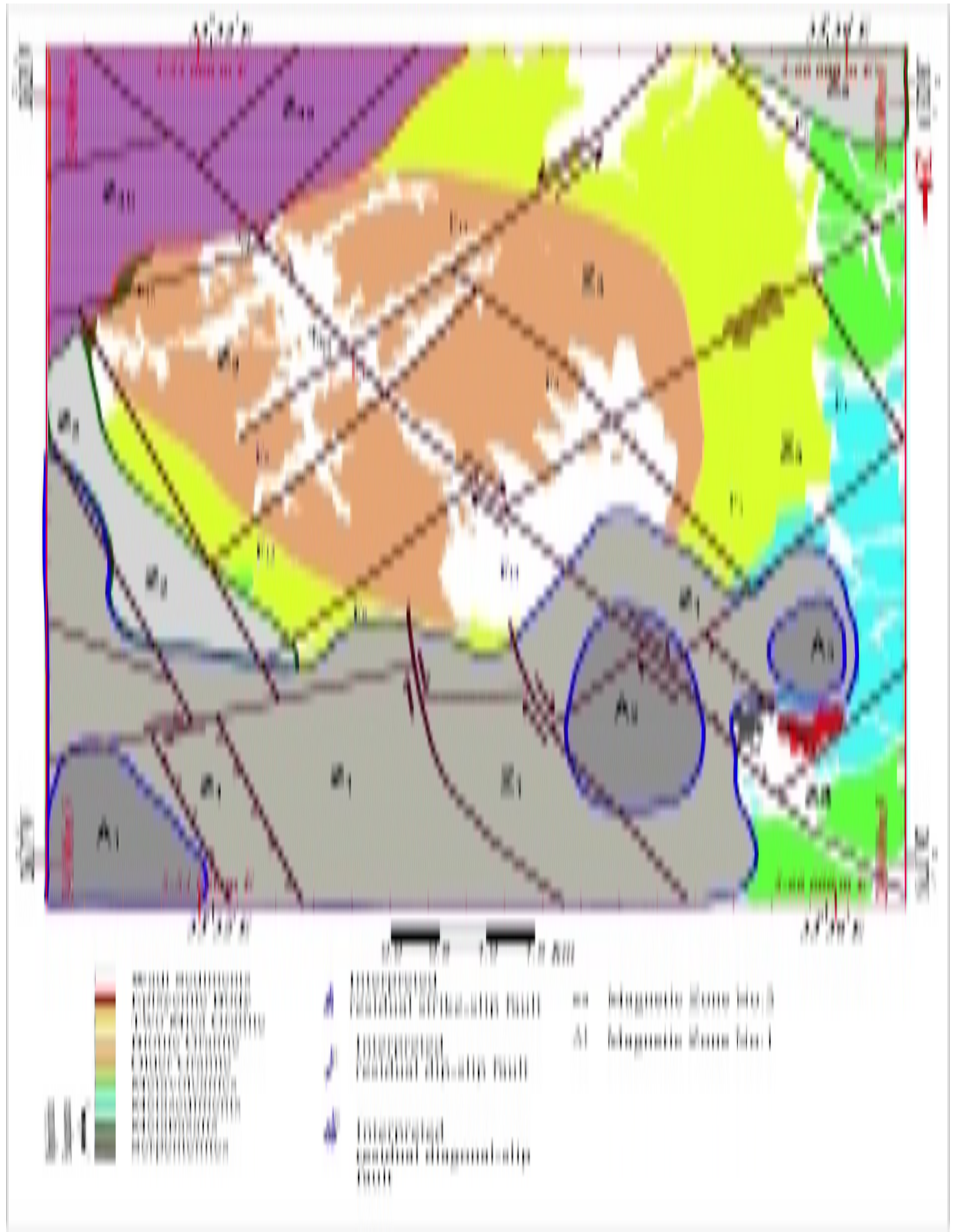

Fig. (6). Interpreted Basement tectonic map as deduced from the R.T.P. magnetic map, with geologic background for Kab Amiri Area, Central ED, Egypt. 


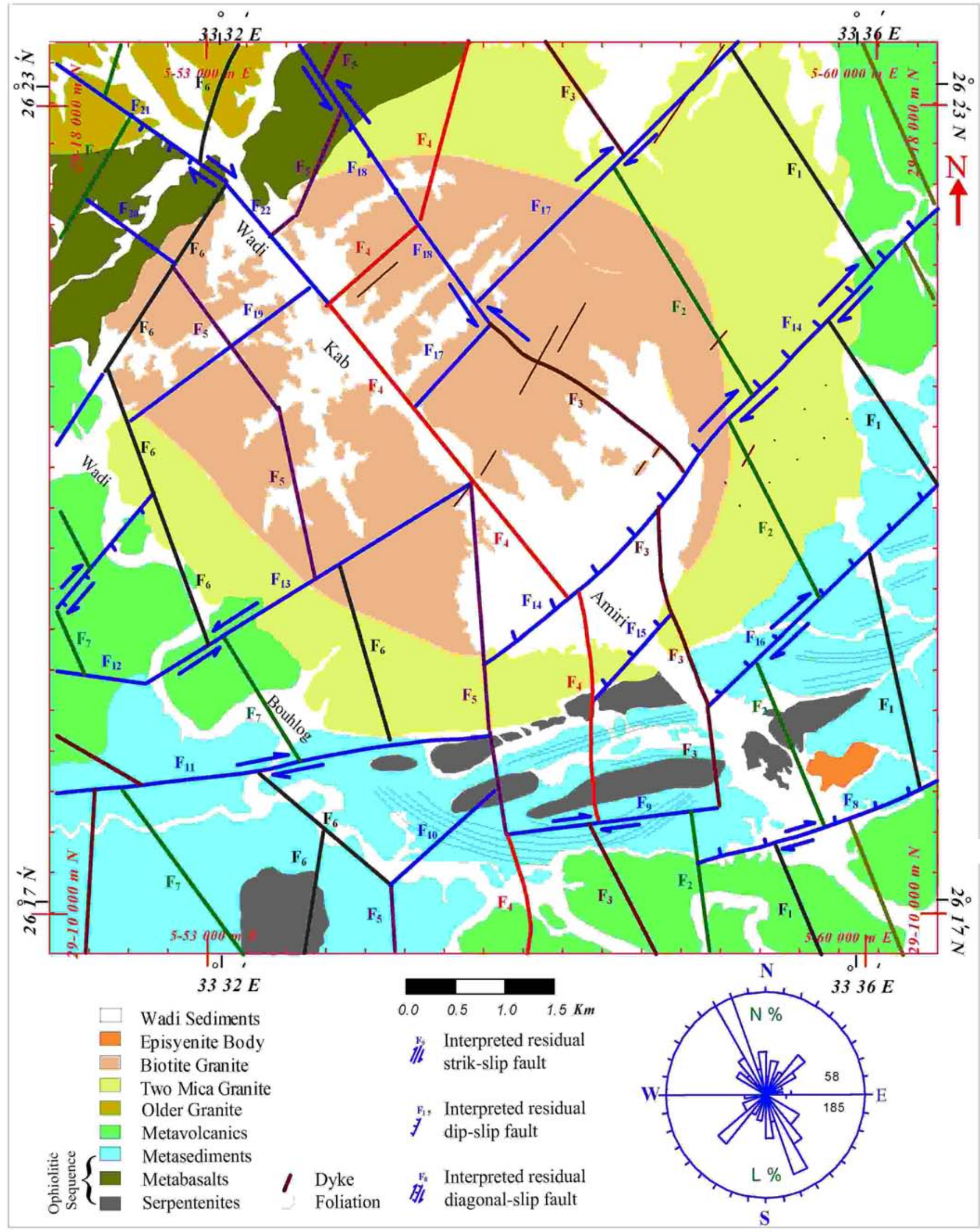

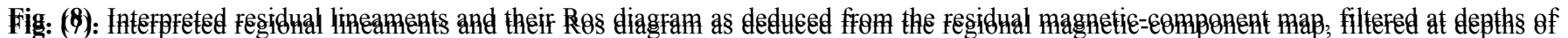

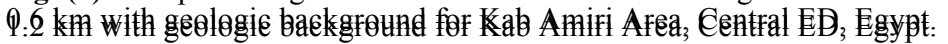


As far as faulting is considered, the interpreted deepseated and near-surface structure maps played a considerable role in the enhancement of the deep-seated and near-surface faulting systems affecting the study area. The predominant orientations and structural trends of faults and lineaments in the study area are quantitatively obtained by applying the rose diagram technique. A rose diagram (Figs. 7, 8), represents the strikes of the interpreted faults from the regional and residual component maps in proportion to their length and number percentage.

\section{Regional (Deep-Seated) Faults}

The interpreted map shows that the regional (deepseated) structures are characterized mainly by two intersecting sets of NE and NW faults. The lineaments at the southwestern and at the northeastern part of the study area may be interpreted as deep-seated geologic contacts rather than faults, since they are associated with deep magnetic gradients. The interpreted NW-trending faults were interpreted as right lateral strike-slip faults. These deepseated tectonic faults may be related to the development of the Red Sea rift.

The second group of faults comprises those with nearly NNE to ENE trends. At the southwestern part of the study area, the faults represented the deep-seated regional contacts, which are dissected and displaced by the NW trending faults. Meanwhile, other faults are interpreted as dip-slip faults.

\section{Residual (Near-Seated) Faults}

The residual magnetic-component map reveals two intersecting sets of NW and NE-trending faults (Fig. 5). The $\mathrm{NW}$-trending set of faults is younger than the NE-trending set where the latter is dissected and displaced by the former.

The first set of interpreted faults are trends mainly in an NE to ENE direction. Most of these faults are of dip-slip nature with normal displacements. Meanwhile, some NE faults possessing both horizontal and vertical displacements of the similar magnetic anomalies. The NE faults occur with maximum densities at the northwestern part of the study area, suggesting the strong effect of the NE folding.

The second set of faults trending mainly in the NW and NNW directions. The NW directions are located at the eastern, western and northern parts whereas the NNW directions are located at the central and southern parts of the study area. The deviation of the trend from the NW to the NNW may refer to the later effect of ENE trending faults. The NW-trending faults are well developed in the study area, because they dissect almost perpendicularly the older folded rocks and shear zones.

\section{GROUND GAMMA-RAY SPECTROMETRIC SURVEY}

\section{Data Acquisition and Survey Design}

The instrument used in the present ground gamma-ray spectrometric survey is a portable 256-channel spectrometer
GS-256 with 3" X 3" NaI (T1) detector designed by Geofyzika Brno-Czech Republic. The determinations of potassium, uranium and thorium are based on measurements of gamma radiation from the decay of ${ }^{40} \mathrm{~K}$ for potassium, ${ }^{214} \mathrm{Bi}(1.76 \mathrm{MeV})$ in the ${ }^{238} \mathrm{U}$ decay series and from ${ }^{208} \mathrm{~T} 1$ (2.62 $\mathrm{MeV}$ ) in the ${ }^{232} \mathrm{Th}$ series. The primary decay of potassium ${ }^{40} \mathrm{~K}(1.46 \mathrm{MeV})$ is measured directly.

Multichannel radiometric measurements were made at an equal grid, with spacing $400 \mathrm{~m}$ along the whole area with an increase of the grid stations to about $50 \mathrm{~m}$ spacing on the areas showing high recordings. In the present study the spectrometric contour maps were prepared and subjected to qualitative and quantitative interpretation to determine lithologic contacts, faults, radioactive anomalies and associated mineralization.

\section{ANALYSIS AND INTERPRETATION OF GAMMA RAY SPECTROMETRY DATA}

\section{Distribution of Radioelements in Kab Amiri Pluton}

The spectrometric data are represented using six contour maps showing the three radioelements (K, U, Th), and their geochemical ratios $\mathrm{eTh} / \mathrm{K}$ and $\mathrm{eU} / \mathrm{eTh}$, as well as eU(eTh/3.5). All these maps have been superimposed on the geologic map of the area to help in vetting the variations which are important in the geochemical prospecting and establishing the U-distribution and mobilization (Figs. 9-14). Statistical analyses (Table 1) of the gamma ray spectrometric data were carried out to delineate anomalies. Spectrometric anomalies could be related to the prevailing faulting directions NE and ENE fault trends.

\section{Equivalent Thorium Surface Distribution Map}

The equivalent thorium content contour map (Fig. 9) shows that the granite of Kab Amiri is generally bound by 5 ppm counter line. The eTh-content of the biotite granite is delineated by contour lines, ranging in intensity from 10 to $25 \mathrm{ppm}$. It is represented as zones of different shapes affected by the structural setting of the pluton. Fig. (9) also shows five Th-anomalies that have elongated or oval shapes and trend in the E-W, NW and NE, N-S directions. An eTh anomaly coincides with the episyenite body, trend in the NE direction and has high values up to $50 \mathrm{ppm}$ (Table 1). These Th anomalies are present in the two-mica granites and in the episyenite body.

\section{Potassium Surface Distribution Map}

The distribution pattern of $K$ (Fig. 10) shows that the coarse-grained biotite granite has a range of $2-4.5 \%$ (Table 1). The two-mica granite has higher levels of concentration and ranges from 4.4 to $6 \%$ (Table 1 ). Two $\mathrm{K}$ anomalies ( $>$ $5.5 \%$ ) coincide with the two mica granite (Fig. 10). Both are related to the Th-anomalies shown in the thorium contour map. These anomalies have elongated shapes and trend in the NE direction. The episyenite zone has the highest $\mathrm{K}$ concentration $(>6 \%)$ in the area. It is encountered as anomaly K-6 of nearly oval shape, trending in NE direction, which is related to the dominant NE faults in the area. 


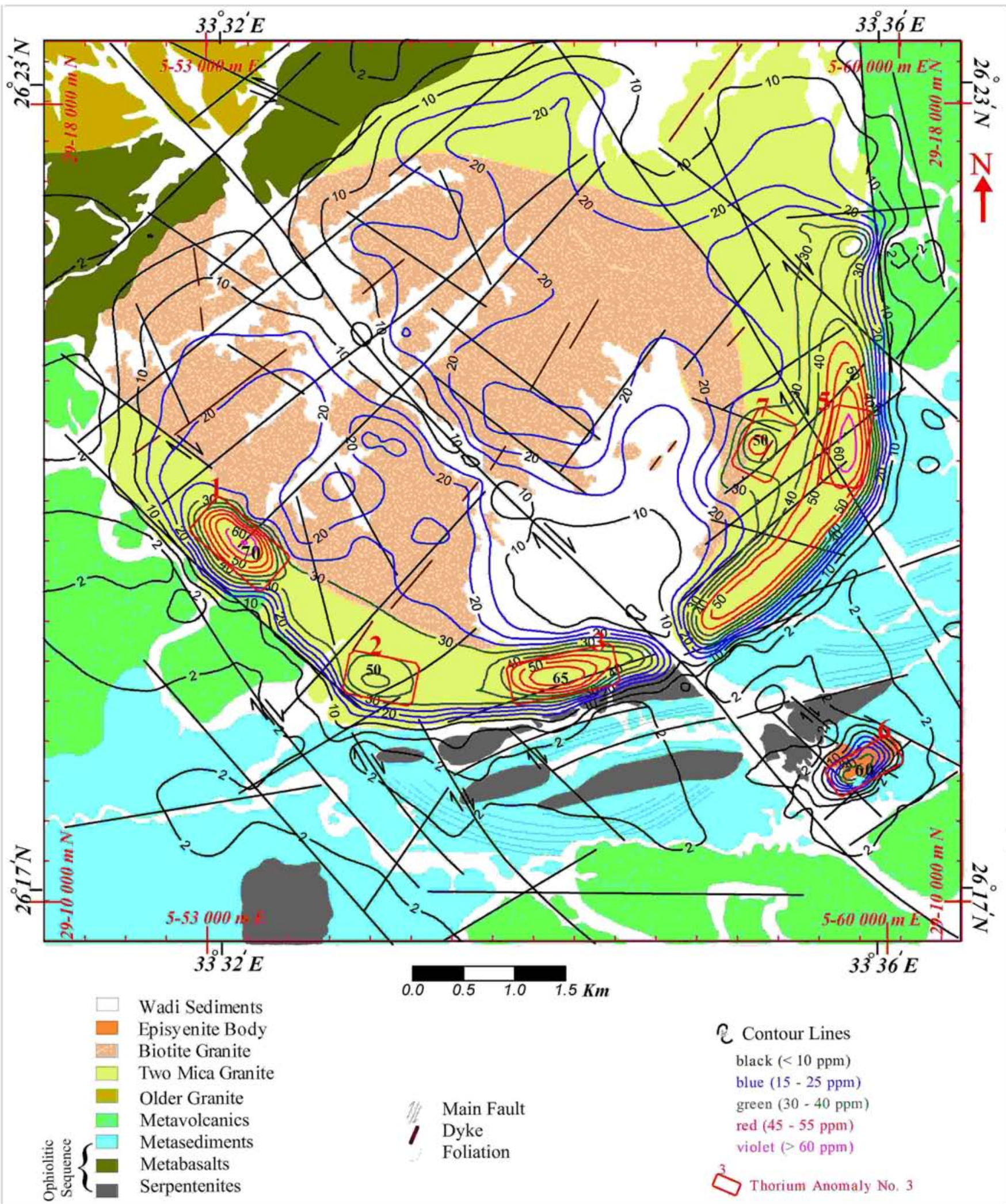

Fig. (9). Equivalent Thorium (ppm) contour map with geologic background for Kab Amiri area, Central ED, Egypt.

\section{Equivalent Uranium Surface Distribution Map}

The equivalent uranium distribution map of Kab Amiri area (Fig. 11) shows that $3 \mathrm{ppm}$ eU counter can separate the granitic pluton from the country rocks. The equivalent uranium content measured over the country rocks varies between $<1$ to $3 \mathrm{ppm}$. A moderate level $(2-5 \mathrm{ppm} \mathrm{eU})$ is observed over the wadi deposits within and around the granitic pluton. The equivalent uranium range (4-12 ppm $\mathrm{eU}$ ) is located over the inner zone of granitic pluton and the 


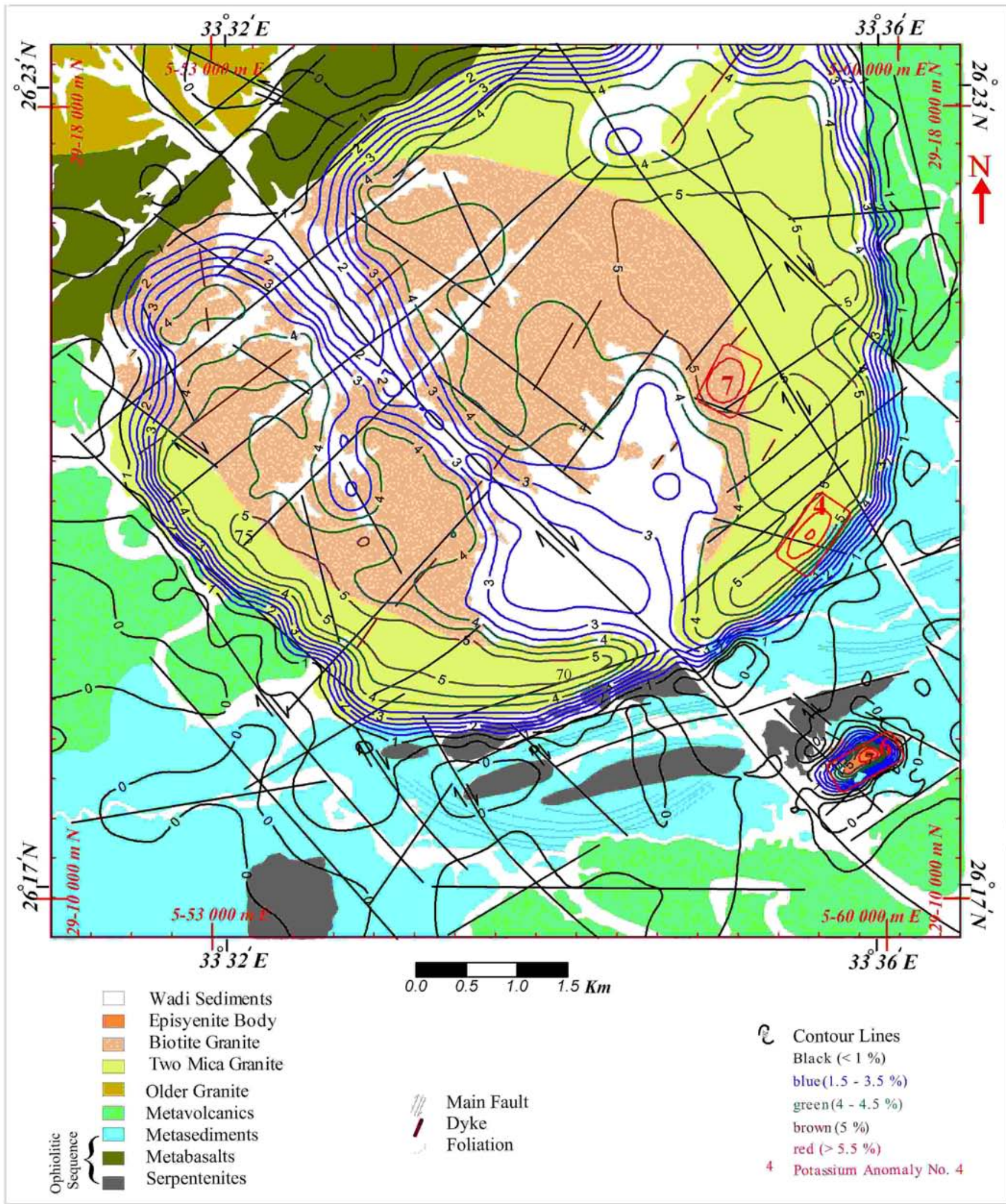

Fig. (10). Potassium (\%) contour map with geologic background for Kab Amiri area, Central ED, Egypt.

northern part of the outer zone. It is encountered as zones with different shapes, which controlled with the main trends of the faults in the study area.

Most of the outer zone of the granitic pluton display equivalent uranium content between 10 to $370 \mathrm{ppm}$ eU. It also appeared as elongated zones trending in an NW and NE directions along the periphery of the pluton. It shows a sharp contact with the country rocks and a gradational contact with the biotite granite. The anomalous zones of equivalent uranium contents $(>16 \mathrm{ppm})$ are located at the south eastern, 


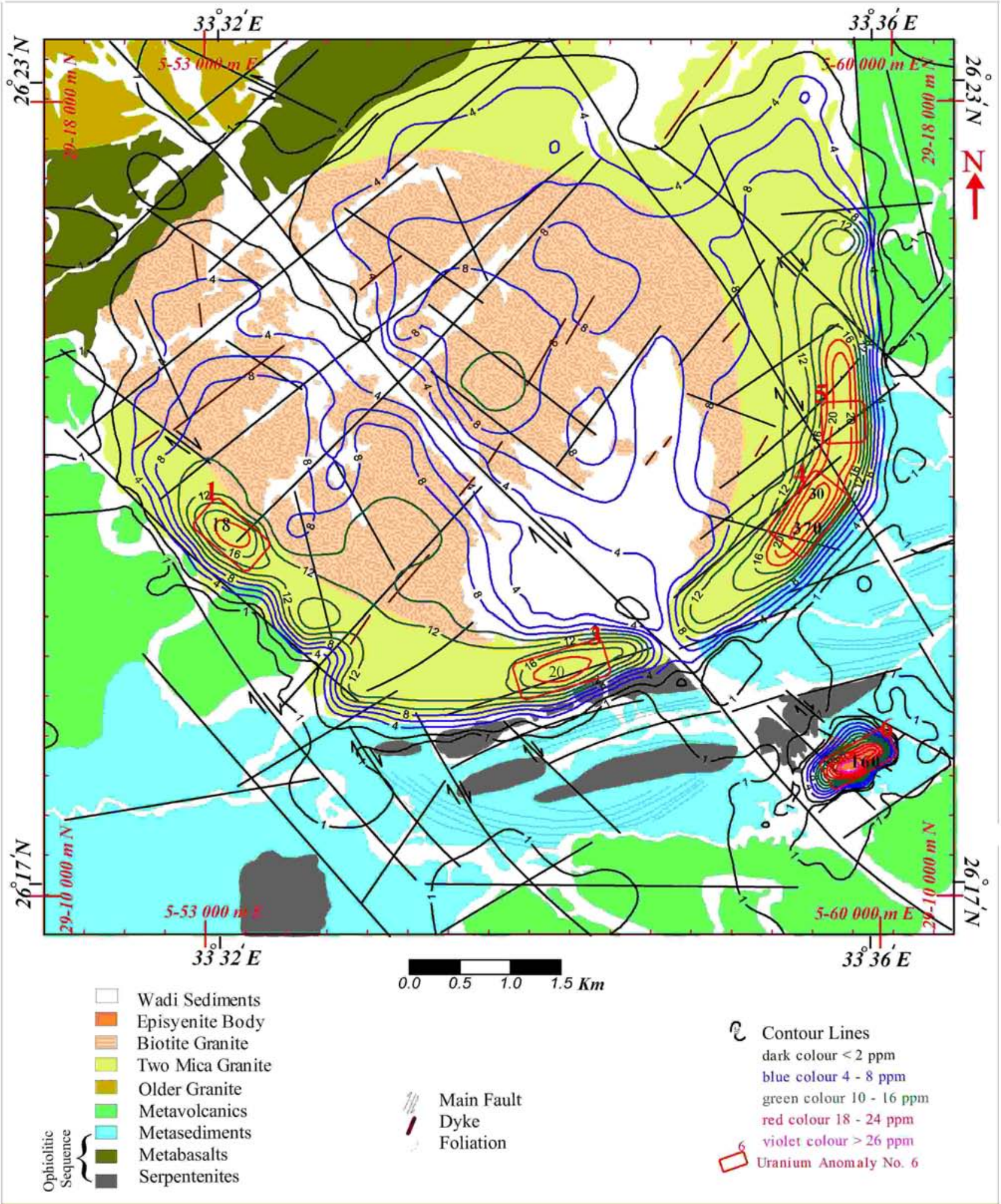

Fig. (11). Equivalent Uranium (ppm) contour map with geologic background for Kab Amiri area, Central ED, Egypt.

and western peripheral parts of the two mica granite (Fig. 11).

\section{Ratio Maps}

One of the more useful arithmetic combination is the ratio of the two radioelement grids. The effect of environment factors on radiometric response, such as soil moisture, vegetation, and topography, are less evident on radioelement ratios. The ratios, therefore, often correlate more highly with the geological units. Also, because there is usually a high correlation between radioelements grids, the ratios often show subtle features that are not apparent on abundance maps [6]. Two ratio maps (eU/eTh and $\mathrm{eTh} / \mathrm{K}$, as 

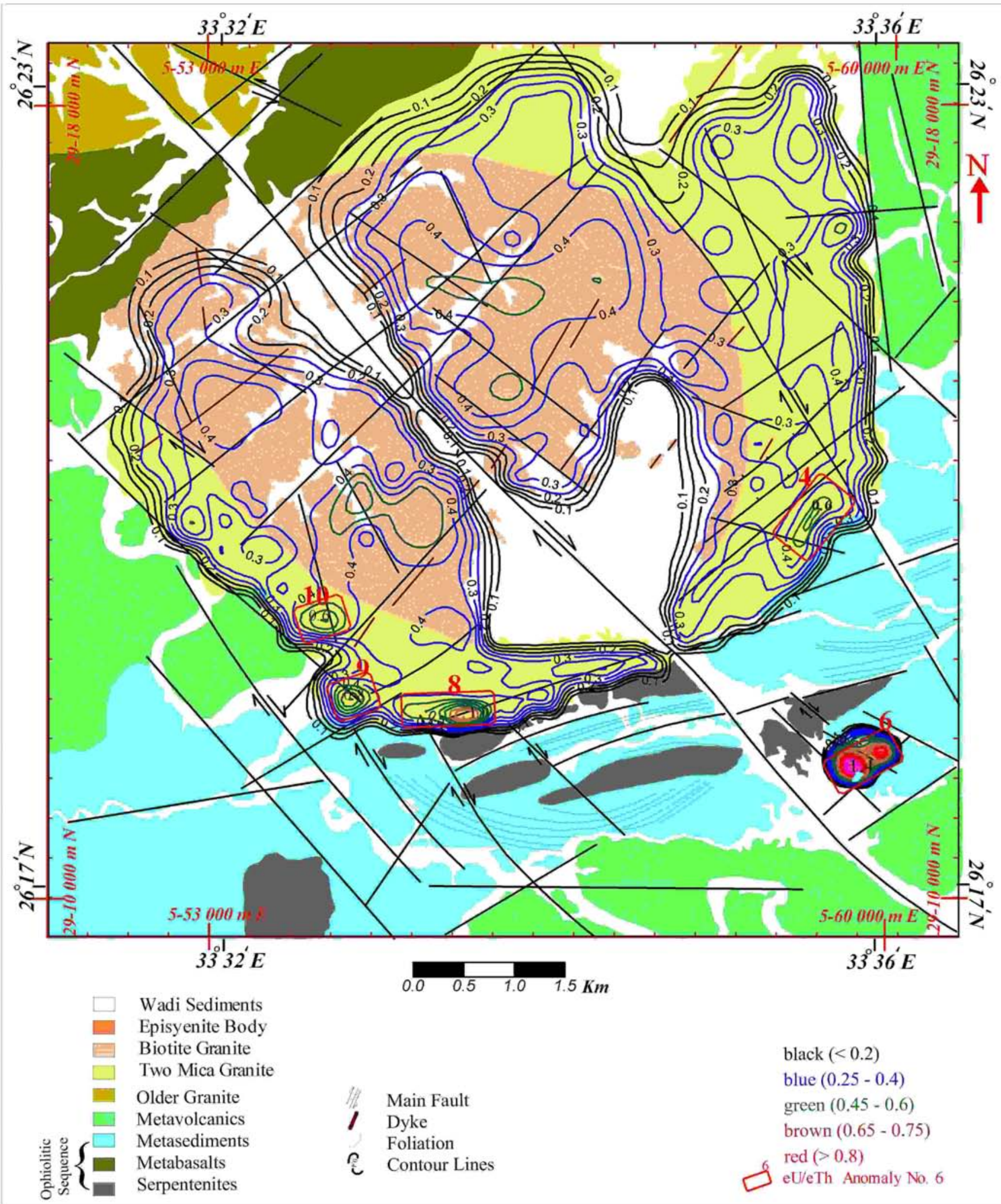

black $(<0.2)$

blue $(0.25-0.4)$

green $(0.45-0.6)$

brown $(0.65-0.75)$

red $(>0.8)$

eU/eTh Anomaly No. 6

Fig. (12). eU/eTh ratio contour map with geologic background for Kab Amiri area, Central ED, Egypt.

well as eU-(eTh/3.5)) map were constructed for the study area as shown in Figs. (12-14). Statistical analyses (Table 2) of the radioelement ratio data were carried out to delineate high spectrometric anomalies.

\section{eU/eTh Ratio Map}

According to Clark et al. (1966) [16], the eU/eTh ratio equals about 0.33 in granitic rocks. The eU/eTh ratio depends mainly on the mobile elements (i.e., uranium). So, this ratio is important for uranium exploration, because it 


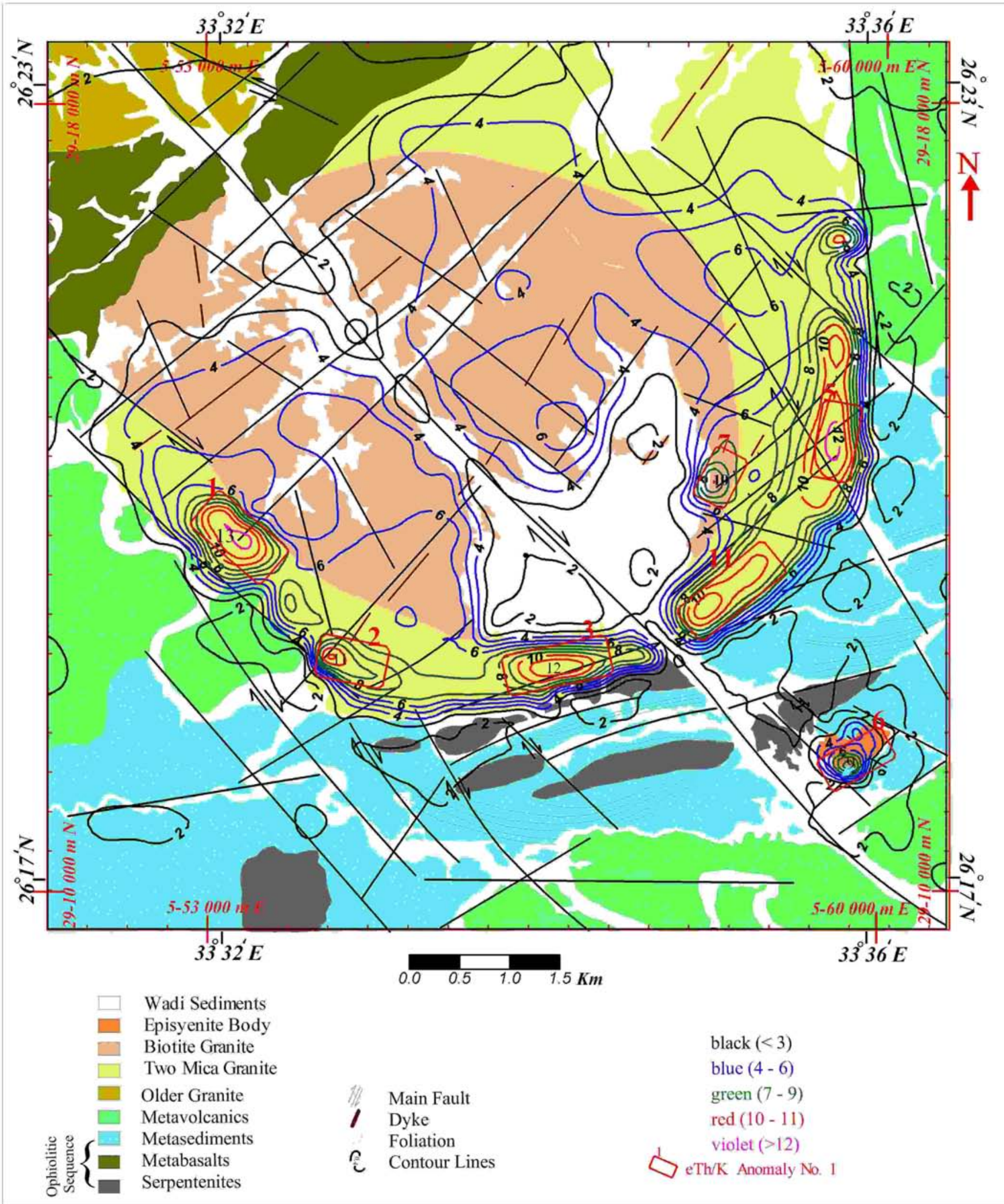

Fig. (13). eTh/K ratio contour map with geologic background for Kab Amiri area, Central ED, Egypt.

determines the uranium enrichment areas. This enrichment is represented by an increase of this ratio above 0.33 in granites, while leaching out of uranium will be indicated by its decrease to less than 0.3 .
Most of the anomalous high eU/eTh ratios are related to the two mica-granite (Table 1) and follow the intersection of the N60E faults with other trends especially the $\mathrm{N} 50^{\circ} \mathrm{W}$ faults (Fig. 12). Also, the southeastern episyenite body has a prominent anomaly of eU/eTh, with ratio of 4.5. In general, 


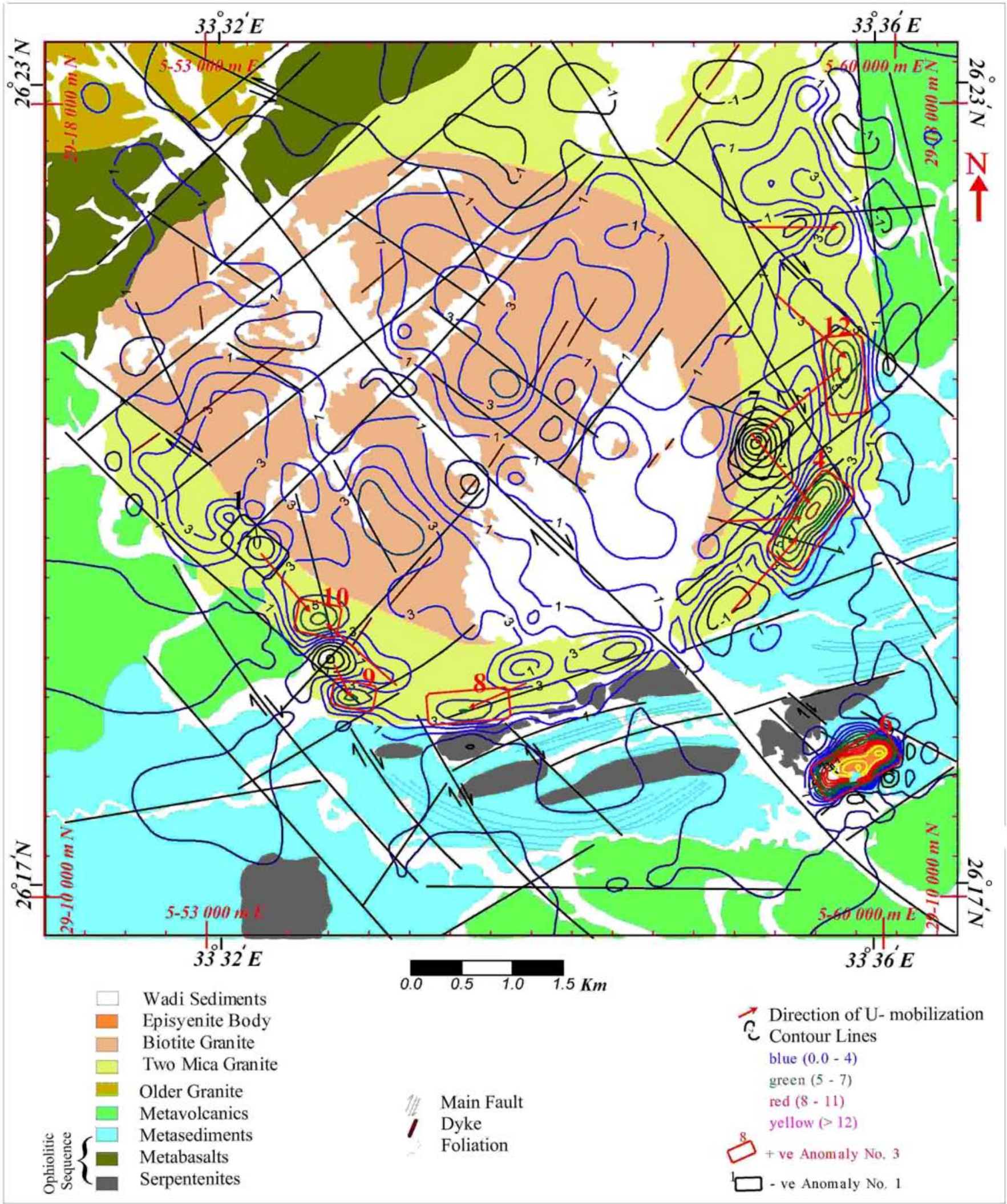

Fig. (14). eU-(eTh/3.5) contour map with geologic background for Kab Amiri area, Central ED, Egypt.

these high eU/eTh ratios compared to the normal crustal ratio of 0.28 are restricted to granitic areas characterized by uranium enrichment.

\section{eTh/K Ratio Map}

The low eTh/K ratio can easily detect the alteration zone. Because thorium, as a stable element, reflects original 
Table 1. Summary Statistics of Various Radioelements and their Ratios in the Kab Amiri Area

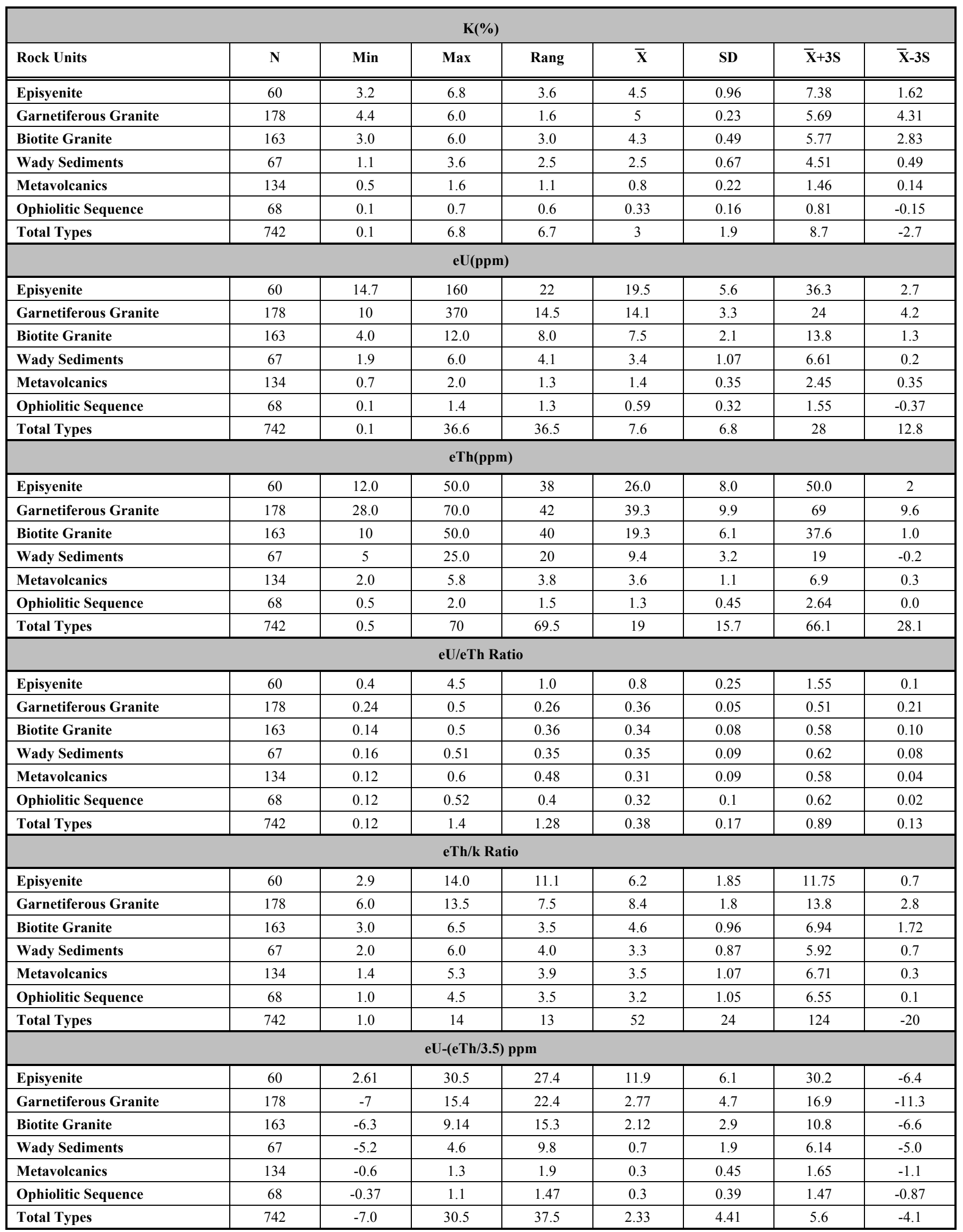


"pre-alteration" compositions, thorium levels permit easy field distinction of different granitic units mistakenly mapped as one type. While spectrometry cannot directly locate the base and precious metals, it can detect the $\mathrm{K}$ alteration associated with an epithermal system and can assist in mapping at both regional and local scales.

The moderate level (3-6 eTh/K ratio) is mainly related to biotite granite (Fig. 13). The high level is associated with the two mica granite and the episyenite body (Table 1). The high-eTh/K ratio is encountered as zones of elongated shapes, mostly trending in the NW, NE and NNE directions, which are the main fault trends in the study area.

\section{eU-(eTh/3.5) Map in ppm}

Uranium is a mobile element and converts from four oxidizing state to six oxidizing state. It has the ability to react with other elements and migrate from its source to another position. In order to understand uranium remobilization in the area, the expected original contents of uranium is calculated by dividing eTh content by the Clark [16] $(\mathrm{eTh} / \mathrm{eU})$ ratio (3.5) in granite ${ }^{16}$. The result is the hypothetical uranium distribution [17]. It is helpful in defining the trends of uranium migration. Also, constructing the contour map (Fig. 14) of eU-eTh/3.5 delineates the limit between the negative contours (leaching) and positive contours (deposition).

According to Fig. (14), there are four levels of radioactivity. 1) A very low level that represents the leached zones $(-0.7-0)$, associated with the three two-mica granites localities, one in the western side (represented by the negative anomaly No. (1) and the other two in the eastern side (represented by negative anomalies No. (7) and (13). 2) A high level that ranges from 4 to $7 \mathrm{ppm}$ (Table 1), with narrow elongated zones associated with the two-mica granite as well as one spot that coincides with the episyenite body. 3)A very high level that ranges from 7 to $30.5 \mathrm{ppm}$ (Table 1), encountered as circular shapes associated with a small body, at the western side, of two-mica granite and anomalies numbers (4) and (12) located in the eastern part of it. 4) The highest anomaly number (6), associated with the episyenite zone.

From the alternating negative and positive anomalies, especially that associated with the two-mica granite, the direction of the uranium mobilization can be traced with directions trending from the negative anomalies to the high positive ones as shown by the red arrows in Fig. (14).

The outer core of the granitic pluton is marked by eU peaks, which are associated with anomalies of eU-(eTh/3.5) and eU/eTh. This increase in uranium content is accompanied by an increase in the muscovite/biotite ratio (Table 1).

\section{DISCUSSION}

The main trends of faults that controlled the radioelement anomaly pattern obtained from the interpretation of geologic and aeromagnetic data in the study area were the TransAfrican (NE), the Gulf of Suez-Red Sea (NW), the Najd (WNW), the Gulf of Aqaba (NNE), and NNW. Rabei et al. (1994) [18] showed the existence of several sets of faults trending in six directions. Five trends agree with the results of the present study, however the sixth one trends N-S.

There is an increase in $\mathrm{K} \%$ toward the outer zone of the granitic pluton, this increase indicates that the outer zone is more fractionated, while the anomalys in parts of the outer zone are usually episyenite and related to faults.

A higher and wider range of eTh-content (28-70 ppm) characterizes the two-mica granite and episyenite body. The Th anomalies indicate that both types are more fractionated than the biotite granite. The increase of Th concentration southwards indicates an original increase in $U$ contents in the same direction. These results did not agree with AbdelMonem et al. (1984) [19] who reported that the Th is very much depleted, ranging 1-5.5 ppm with no distribution pattern.

The more prevalent inverse relationship between uranium and thorium results in high $\mathrm{eU} / \mathrm{eTh}$ ratios associated with the more differentiated phases of the granitic suite. Thus it can be shown that variation in the $\mathrm{U}$ and $\mathrm{Th}$ concentrations and hence the U/Th are useful lithogeochemical indicators of areas of specializations, such as episyenite within the granitic rocks which exhibits sharp increase in the eU concentrations resulting in a high eU/eTh ratio. The eU/eTh ratio agrees with the result of Ammar [4] (1993).

This relationship of increasing uranium content superimposed a constant thorium content which is, however not characteristic of all granitic rocks of the main pluton. To the southern part of the two-mica granite there are three $\mathrm{eU} / \mathrm{eTh}$ anomalies that lie in the intersection between the two faults striking in NE and NW directions. Other low-level $\mathrm{eU} / \mathrm{eTh}$ anomalies range from 0.4 to 0.5 with different shapes distributed all over the biotite granite. These relatively high $\mathrm{eU} / \mathrm{eTh}$ ratios associated with the biotite granite appear to be the result of decreasing eTh levels superimposed on a relatively constant eU level.

Some of the thorium anomalies do not show uranium anomalies indicating secondary remobilization of the original uranium through episyenitization process, which increase southwards and reaches its maximum in the southern episyenite body. Southeast of the pluton, equivalent uranium reaches $60 \mathrm{ppm}$ eU and sometimes more than 160 ppm eU. These results agree with Abdel-Monem et al. [19] (1984) who registered uranium content in the unaltered granite range between 16-28 ppm and between 44-169 ppm in the radioactive zone associated with an episyenitized granite stock exposed to the south of the main pluton. This second remobilization leads to an increase in uranium concentration southwards and decrease it northwards. In addition, local increases in uranium along faults may indicate alteration southwards which controls uranium concentrations.

In the biotite-muscovite granite, some uranium seem to have been expelled outwards to the edge of the intrusion and into the wall rocks creating a flanking eU/eTh ratio anomaly. This anomaly may also be related to the escape of volatiles (plus uranium) with pressure release related to upward movement of the diaper [20].

Anomalous areas in the outer zone have $\mathrm{eTh} / \mathrm{K}$ ratio higher than $9 \mathrm{ppm} \mathrm{eTh/K}$ indicate the relative increase of 
uranium during fractionation towards the periphery of the pluton. The decrease of $\mathrm{eTh} / \mathrm{K}$ ratio in some parts of the high eTh and eU peripheral zones is a good indication of episyenitization. Some areas along the peripheral part of the outer zone are episyenitized and show a remobilization of uranium. These areas are mostly controlled by faults (mainly trending ENE) and/or the intersection of the ENE with the NNW faults.

In the case of the episyenite zone the uranium has been reconcentrated in carbonatization, muscovitization, hematization, episynitization alteration and in fractures. Strong mobilization of uranium in the episyenite zone is expected to host epigenetic uranium occurrences because more uranium is available.

From the above discussion, it is obvious that the episyenite rocks of high permeability have higher levels of uranium and their ratios. Thus these rocks act as an important reservoir for $\mathrm{U}$ - mineralization bearing solutions.

\section{CONCLUSIONS}

The Kab Amiri pluton is one of the most favorable uranium areas in the Central Eastern Desert of Egypt. Detailed geological and field studies revealed that the Kab Amiri pluton forms two concentric zones. The outer zone ranges from 0.5 to $1.5 \mathrm{~km}$ in width enveloping the inner one. The latter is low relief and consists of whitish pink granite while the outer zone is represented by pink granite and is higher in relief. The outer zone is higher in radioactivity. The pluton sends some offshoots to the country rocks, especially at the southeastern side. The largest muscovite granite and episyenite offshoot (about $200 \times 400 \mathrm{~m}$ ) crops at the southeastern side of the Kab Amiri pluton.

Two main average magnetic interfaces at depths 0.5 and $1.2 \mathrm{~km}$ below the measuring level were calculated through the application of power spectrum technique. Filtering assisted in the discrimination between shallow and deep sources of magnetic anomalies and produces the regional and residual magnetic component maps and hence the two basement tectonic maps were constructed.

The interpreted map showing the regional structures is characterized mainly by two intersecting sets of NE and NW-trending faults. The first interpreted group of faults comprises those with a nearly NE trend at the southwestern and the northeastern part of the study area may be interpreted as deep-seated geologic contacts rather than faults, because they are associated with deep magnetic gradients. The interpreted NW-trending faults were interpreted as right lateral strike-slip faults. These deep-seated tectonic faults may be related to the development of the Red Sea rift.

The second group of faults comprises those with nearly a NNE to ENE trend. At the southwestern part of the study area, the faults bhaves as deep-seated regional contacts are dissected and were displaced by the NW trending faults. Meanwhile, other faults were interpreted as dip-slip faults.

The structures, which interpreted from the residual magnetic-component map, are characterized by two intersecting sets of NW and NE-trending faults. The NEtrending set of faults is older than the NW-trending set where the latter is dissected and displaced the first one.
Kab Amiri granitic pluton systematically surveyed on a grid pattern using high sensitivity ground gamma-ray spectrometry for determining the surface distribution of the $\mathrm{eU}, \mathrm{eTh}, \mathrm{K}$ and their ratios $\mathrm{eU} / \mathrm{Th}$ and $\mathrm{eTh} / \mathrm{K}$ as well as eU$\mathrm{eTh} / 3.5$ also identify and outline significant radiometric zones of anomalously high uranium concentrations. Contour maps of these elements were constructed and interpreted.

Statistical analyses of the gamma ray spectrometric data were carried out to delineate anomalies. Seven spectrometric anomalies could be related to the prevailing faulting directions NE and ENE fault trends. The southern anomalous zone is related to a very high episyenitization and uranium mobilization. This anomaly is restricted to areas characterized by either elevated levels of uranium and/or depleted levels of thorium. It exhibits a sharp increase in the $\mathrm{eU}$ concentrations reaching $370 \mathrm{ppm}$ and a high $\mathrm{eU} / \mathrm{eTh}$ ratio reaching 4.5 and is characterized by an oval shape trend in the NE direction. There is an increase in $\mathrm{K} \%$ toward the outer zone of the granitic pluton, this increase indicates that the outer zone is more fractionated while the anomalous parts at the outer zone are usually episyenite and related with faults. The episyenite rocks of high permeability have higher levels of uranium and their ratios. Thus these rocks act as an important reservoir for $\mathrm{U}$ - mineralization bearing solutions.

Constructing the contour map of eU-eTh/3.5 is very helpful in defining the trends of uranium migration and enables the delineation of the limit between the negative contours (leaching) and positive contours (deposition). From the alternating negative and positive anomalies especially those associated with the two-mica granite, the directions of the uranium mobilization were traced with arrows trending from the negative anomalies to the positive ones.

Future geological and geophysical (gamma ray spectrometry, ground magnetic and VLF) surveys with a closed grid on the episyenite zone will be recommended for the study area. This study will be useful in detecting and evaluating uranium anomalies as well as conducting a case study to be used as a guide for the evaluation of potential areas.

\section{CONFLICT OF INTEREST}

The authors confirm that this article content has no conflict of interest.

\section{ACKNOWLEDGEMENTS}

The authors thank the Geologic Studies Department in the Nuclear Materials Authority of Egypt for providing the portable gamma ray spectrometer GS-256 that was used in ground gamma ray spectrometry survey. They also thanks Dr. Tarek Ibrahim and Dr. Khaled Gamal in the Geologic Studies Department for their help and support during field work and Grateful are to Prof. Dr. Ahmed A. El Metwally, Geology Department, Faculty of Science, Mansoura University for his assistant revisions and fruitful discussions.

\section{REFERENCES}

[1] Stern RJ. Late Precambrian crustal environments as reconstructed from relict igneous minerals, Central Eastern Desert of Egypt. Ann Geol Surv Egypt 1979; 9: 9-31. 
[2] Abdel Meguid AA. Late Proterozoic Pan African tectonic evolution of the Egyptian part of the Arabian-Nubian Shield. Earth Sci Serv 1992; 6: 13-28.

[3] Aboelkhair H, Gaafar I. The Use of Gamma Ray Spectrometry as an Aid for Uranium Exploration in Kab Amiri Area, Central Eastern Desert, Egypt. Resour Geol 2013; 63: 72-83.

[4] Ammar SE. Geological, structural and geochemical investigations of Kab Amiri-Wadi El-Saqia area and its radioactive occurrences Central Eastern Desert, Egypt, Ph. D. Thesis, Faculty of Science, Cairo Univeristy, Egypt 1993.

[5] Aboelkhair H, Rabie M. Radioelement mapping and environmental monitoring of surface deposits using ground gamma ray spectrometry of the area adjacent to El-Ramlah Village, Southwestern Sinai, Egypt. Resour Geol 2012; 62: 215-24.

[6] International Atomic Energy Agency (IAEA). Guidelines for radioelement mapping using gamma ray spectrometry data. IAEATECDOC-1363, Vienna, Austria 2003.

[7] International Atomic Energy Agency (IAEA). Radioelement mapping. IAEA nuclear energy series, No. NF-T-1.3, Vienna, Austria 2010.

[8] Foote RS, Humphrey NB. Airborne radiometric techniques and applications to Uranium exploration, Exploration For Uranium Ore (1AEA-SM-208/47). IAEA: Vienna 1976.

[9] Saunders DF, Potts MJ. Interpretation and application of high sensitivity airborne gamma ray spectrometer data; in Exploration for Uranium Ore Deposits, Proc. Series, IAEA, Vienna, 1976; 10725.

[10] Mekonnen TK. Interpretation and geodatabase of dykes using aeromagnetic data of Zimbabwe and Mozambique. M.Sc. Thesis, ITC, Delft: The Netherlands 2004.
[11] Srcia JA. Cottages and deposits Northern Limousin. In: The uranium-bearing ores French. Paris: P.U.F. 1962; 190-292.

[12] Leroy J. Les episyenites non mineralsees dans le massif de granite a deux micas de Saint Sylvestre. Equilbre entre mineraux et solutions, Unpublished thesis, Nancy 1 University, 1971.

[13] Gaafar IM. Geologic and gamma-ray spectrometric studies of Kab Amiri granites and their uranium potentiali-ties, Eastern Desert, Egypt. Unpublished M.Sc. Thesis, Faculty of Science, Mansoura University 2000; p.166.

[14] Youssef MI. Structural pattern of Egypt and its interpretation. AAPG Bull 1968; 52: 601-14

[15] Mohamed Youssef AS, Shadia TE. Interpretation report of airborne gamma-ray spectrometer and magnetometer survey of the Eastern Desert of Egypt. Geophys J Int 1984; p.127.

[16] Clark SP, Peterman ZE, Heier KS. Abundances in uranium, thorium and potassium. Handbook of physical constants. Geol Soc Am Mem 1966; 97; 521-41.

[17] Cambon AH. Uranium deposits in granitic rocks. In Notes on the National Training Course on Uranium Geology and Exploration. IAEA and NMA, 8-20, Cairo, Egypt 1994.

[18] Rabie SI, El-Kattan EM, El-Sirafy AM. Structural interpretation of airborne magnetic survey data in the Kab Amiri area, Central Eastern Desert, Egypt. Arab J Sci Eng 1994; 19: 640-63.

[19] Abdel-Monem AA, Hussein HA, El-Taher MA, Ammar SE. Radioactivity and origin of U-mineralization at the Kab Amiri area, central eastern desert, Egypt. Radiat Phys Chem 1984; 44: 207-14.

[20] Bostock HH. A granitic diapir of batholithic dimensions at the west margin of the Churchill Provinces. Geol Surv Can 1981; 81-1B: 73-82.

(C) Gaafar and Aboelkhair; Licensee Bentham Open.

This is an open access article licensed under the terms of the Creative Commons Attribution Non-Commercial License (http://creativecommons.org/licenses/by$\mathrm{nc} / 3.0 /$ ) which permits unrestricted, non-commercial use, distribution and reproduction in any medium, provided the work is properly cited. 